\title{
Nutritional Composition and Effects of Cultural Processing on Anti-nutritional Factors and Mineral Bioavailability of Colocasia Esculenta (Godere) Grown in Wolaita Zone, Ethiopia
}

\author{
Habtamu Azene*, Tesfahun Molla \\ School of Medicine, College of Health Science and Medicine, Wolaita Sodo University, Wolaita Sodo, Ethiopia
}

Email address:

hahab.azene@gmail.com (H. Azene)

${ }^{*}$ Corresponding author

To cite this article:

Habtamu Azene, Tesfahun Molla. Nutritional Composition and Effects of Cultural Processing on Anti-nutritional Factors and Mineral Bioavailability of Colocasia Esculenta (Godere) Grown in Wolaita Zone, Ethiopia. Journal of Food and Nutrition Sciences. Vol. 5, No. 4, 2017, pp. 147-154. doi: 10.11648/j.jfns.20170504.12

Received: May 11, 2017; Accepted: June 5, 2017; Published: June 29, 2017

\begin{abstract}
Taro corms of Boloso variety grown in southern region of Ethiopia was exposed to processing such as boiling, frying and fermentation were investigated for proximate, mineral and anti-nutritional factors. Proximate compositions of Boloso raw were found to contain moisture- $67.64 \%$, crude ash $-3.92 \%$, crude fiber- $5.8 \%$, crude protein- $6.62 \%$, crude fat0.67\%.Macro nutrients such as phosphorous, sodium, Potassium, and calcium were $60.63 \mathrm{mg} / 100 \mathrm{~g}, 37.61 \mathrm{mg} / 100 \mathrm{~g}, 710$ $\mathrm{mg} / 100 \mathrm{~g}$ and $186 \mathrm{mg} / 100 \mathrm{~g}$ respectively. The mineral composition of micro nutrients found to be copper- $0.76 \mathrm{mg} / 100 \mathrm{~g}$, zinc$14.27 \mathrm{mg} / 100 \mathrm{~g}$, iron- $10.57 \mathrm{mg} / 100 \mathrm{~g}$ for Bolos raw. Anti-nutrient factor of Boloso raw analyzed in this study were oxalate-187 $\mathrm{mg} / 100 \mathrm{~g}$, Phytate- $78.11 \mathrm{mg} / 100 \mathrm{~g}$, tannin- $67.07 \mathrm{mg} / 100 \mathrm{~g}$. Potassium was the most abundant macro mineral $(710 \mathrm{mg} / 100 \mathrm{~g})$ in the unprocessed tubers. Processing significantly reduced its content. The effect of processing on calcium showed significant increase upon fermentation and decrease on frying process. However, boiling did not significantly reduce the calcium content. When compared with Boloso raw, processing resulted in significant increase phosphorous and sodium content. Bolo raw has the highest zinc content. Frying process significantly reduced micronutrients where as fermentation process significantly reduced zinc and iron content. Boiling process significantly increased copper content but it decreased iron content significantly. Boloso raw is rich in calcium oxalate. Anti-nutrient factors were significantly reduced by the effects of various domestic processing (boiling, frying and fermentation) on Bolos raw taro. Of the three different treatments boiling appears to be effective in reducing oxalate, fermentation in phytate and frying in tannin content.
\end{abstract}

Keywords: Colocasia Esculenta, Nutritional Value, Anti-nutrients, Processing

\section{Introduction}

A community will accept certain foods as suitable for their consumption and these foods, because of custom and the people's partiality towards them, become regarded as traditional food crops. There are many examples of plant foods consumed as traditional dietary staples that are indigenous to Africa - for example: cassava, yam, plantain, sweet potato, millets and sorghum [1]. The term taro is used to refer to Colocasia esculenta(L.) Schott. It belongs to the genus Colocasia, within the sub-family Colocasioideae of the monocotyledonous family Araceae. Although, all parts of the cocoyam plant can be eaten, it is grown mainly for its edible root called corm. Taro are underutilized plants found mostly in south and southwest Ethiopia around Metekel, Sidama, Wolayta, Gambella, Maji and North Omo. Underutilized plants when properly harnessed and utilized can reduce malnutrition [2].

In Ethiopia, the local name for taro is Boyna (in Wolaitigna- a language of Wolaita tribe which is located in Southern Nation Nationality People's Region) and Godere (in Amharic-National language of Ethiopia). Taro is one of the most important roots and tuber crops worldwide [3]. It is probably the oldest crop on earth and has been grown in 
tropical Asia for more than 10,000 [4]. It reproduces by vegetative propagation. C. esculentais best adapted in lowlying areas ranging from sea level to $1200 \mathrm{~m}$ elevation and in a warm, moist environment, ideally tropical or subtropical areas with long frost free periods where annual rainfall is well distributed, with $2500 \mathrm{~mm}$ average annual precipitation or more [5].

Taro cultivars are high in easily digestible carbohydrates, phosphorous, calcium, potassium, zinc and vitamin B1, vitamin $\mathrm{B} 2$ and vitamin $\mathrm{C}$, but low in protein which are important constituents of human diet [1], [6], [7]. When a crop is being utilized as a food source, nutritional value and consumer acceptance have to be taken into consideration. The nutritional value of foods depends largely upon their nutritional contents, digestibility and the presence or absence of anti-nutrients and toxic factors [8]. The anti-nutritional factors found in taro cocoyam include oxalates, proteinase inhibitors, phytates, tannins, alkaloids, steroids and cyanogenic glucosides [9], [10], [11]. In order to reduce the effect of anti-nutrients, which may have some health-hazard potentials, proper processing before consumption is necessary.Cooking improves digestibility, promote palatability, improves keeping quality, and also makes root crops safer to eat [1].

Taro can be processed in many different ways; it can either be boiled, fried, roasted, baked or steamed for consumption. This research was aimed at determining the effect of boiling, fermentation and frying using vegetable oil on the antinutritional factors, proximate and mineral contents of Colocasia esculenta.

\section{Materials and Methods}

\subsection{Raw Materials}

Samples (Boloso variety) were collected from Areka Agricultural Research Center (AARC). All the samples were harvested within 8-10 months of planting, which is the maturation period of taro [12]. The sampling technique used was judgment sampling method. Horticulturists who work in the research center had helped in the selection of the samples. Fresh samples which were immediately harvested from the ground were selected based on the visual examination with the help of experienced persons who worked in the area for many years. The taro samples selected contain large, middle, and small corm (cormels) sizes that were not damaged during harvest and they were not attacked by pests. About three kilograms from each size were collected.

The samples were kept in an ice box at about $5^{\circ} \mathrm{C}$ and transported to Addis Ababa. After that, the same day the samples were weighed using a calibrated balance, to avoid enzymatic degradation of phytate and oxalate, the samples were kept in a deep freeze for about three weeks up to the time of analysis.

\subsection{Processing}

Healthy Taro tubers with little or no skin wounding will be selected, washed, hand-peeled and subjected to the following processing techniques:

a. Boiling: in distilled water on a stove for 45 minutes without skin peeled off, after which they were drained.

b. Fermentation: about $100 \mathrm{~g}$ of raw taro washed, peeled, milled and mixed with $300 \mathrm{ml}$ of distilled water in $1000 \mathrm{ml}$ conical flask and the flask was covered with aluminum foil and allowed to ferment naturally (spontaneously) at room temperature for 72 hours.

c. Frying: was done on a baking pan in an oven for 55 minutes at $190^{\circ} \mathrm{C}$ using vegetable oil.

\subsection{Sample Preparation}

Samples (raw, boiled, fried and fermented) are made homogeneous prior to analysis by a procedure that protects labile nutrients. The sample is first frozen and then minced into small pieces. It is cooled in liquid nitrogen and grinded in to a fine powder. The powder is transferred in to the precooled sample bottles and stored at $-40^{\circ} \mathrm{C}$ until required for analysis [13].

\subsection{Chemical Analysis}

The Boloso raw taro corms, Boloso boiled, Boloso fried and Boloso fermented were also analyzed for their proximate composition, mineral, phytochemical and anti-nutrient contents. All the analyses were done at the EPHI (Ethiopian Public Health Institute), Addis Ababa.

\subsubsection{Nutritional Value}

Moisture, crude protein, ash, fiber and fat were analyzed as described in AOAC methods [14]. Carbohydrate (expressed as nitrogen free extract, NFE) was computed by subtracting the moisture, crude protein, ash, fiber and fat from 100 .

\subsubsection{Anti-nutrient Contents}

Acid extraction of condensed tannin analysis was determined using vanillin reagent spectrophotometric method. Oxalate content was determined by titration method using Potassium permanganate as a standard solution. Analysis of phytate was carried out using equal mix of ferric chloride hexahydrated and sulfosalicilic acid (Wade reagent). Absorbance of light was measured at visible range of $500 \mathrm{~nm}$ by spectrophotometer.

\subsubsection{Macro Nutrients}

The amount of sodiumand potassium content was measuredby flame photometer while calcium content was determined using atomic absorption spectroscopic method.

\subsubsection{Micro Nutrients}

Trace metals such as Copper, Iron and Zinc in food and food products were analyzed following the AOAC(1990) dry ashing procedure and standard analytical method for atomic absorption spectrophotometry [14]. After removal of organic material by dry ashing the residue is dissolved in dilute acid. The solution is sprayed into the AAS and the absorption of the metal to be analyzed is measured at a specific wavelength. 


\subsection{Statistical Analysis}

Results of the chemical tests were analyzed using Analysis of Variance (ANOVA), Fisher's Least Significant Difference (LSD). All the statistical tests were performed at $5 \%$ level of significance using SPSS version 20. The results were expressed as mean values \pm standard deviation.

\section{Results}

\subsection{Proximate Composition of Taro}

Moisture content: Table 1 summarizes the proximate composition of Boloso raw, Boloso fried, Boloso boiled and Boloso fermented. Boloso fermented had the highest moisture content at $83.17 \%$ while Boloso fried had the lowest at $38.05 \%$. The results showed that the moisture content of Boloso raw decreased significantly upon frying process while the moisture content significantly increased upon fermentation but boiling increased moisture content which is not significant.

Crude ash: The ash content of Boloso raw showed significant decrease when processed in to boiled and fried but the ash content between Boloso raw and Boloso fermented as well as Boloso fried and Boloso boiled were not significant.

Crude fiber: Boloso raw (5.8\%) had the highest crude fiber in content and Boloso fried (3.77\%) had the lowest. The crude fiber of Boloso raw decreased significantly when made into fermented, boiled and fried.

Crude protein: Boloso raw $(6.62 \%)$ had the highest protein content and Boloso fried (5.1\%) had the lowest. Results showed that there was a significant difference in the crude protein of raw taro and its processed products.

Crude fat: Boloso fried has the highest fat content $(22.42 \%)$ and Boloso boiled has the lowest $(0.35 \%)$.The crude fat of Boloso raw taro increased significantly when processed into Boloso fried then decreased when made (processed) into fermented and boiled.

Table 1. Mean proximate composition of Boloso raw, Boloso fried, Boloso boiled, Boloso fermented.

\begin{tabular}{|c|c|c|c|c|}
\hline components & Boloso raw & Bolosofried & Bolosoboiled & Bolosofermented \\
\hline Moisture(\%) & $67.64 \pm 0.30(a)$ & $38.05 \pm 1.76(b)$ & $68.23 \pm 0.23(\mathrm{a})$ & $83.17 \pm 0.47(\mathrm{c})$ \\
\hline Crude ash(\%) & $3.92 \pm 0.28(\mathrm{a})$ & $2.93 \pm 0.30(\mathrm{~b})$ & $3.08 \pm .0 .7(\mathrm{~b})$ & $3.85 \pm 0.05(a)$ \\
\hline Crude fiber(\%) & $5.8 \pm 0.08(a)$ & $3.77 \pm 0.04(\mathrm{~b})$ & $4.26 \pm 0.06(\mathrm{c})$ & $5.68 \pm 0.0(\mathrm{~d})$ \\
\hline Crude protein( $\%)$ & $6.62 \pm 0.11(\mathrm{a})$ & $5.1 \pm 0.03(\mathrm{~b})$ & $5.96 \pm 0.24(\mathrm{c})$ & $6.32 \pm 0.12(\mathrm{~d})$ \\
\hline Crude fat $(\%)$ & $0.67 \pm 0.01(\mathrm{a})$ & $22.42 \pm 0.01(\mathrm{~b})$ & $0.35 \pm 0.01(\mathrm{c})$ & $0.43 \pm 0.01(\mathrm{~d})$ \\
\hline
\end{tabular}

*Means having the same letter within rows are not significantly different at $\mathrm{p}<0.05$. Data were mean of three determinations $(\mathrm{n}=3)$.

\subsection{Anti-nutrient Content of Taro}

Table 2. Mean tannin, phytate and oxalate contents of raw and processed Boloso species.

\begin{tabular}{llll}
\hline Components & Boloso raw & Bolosofried & Bolosoboiled \\
\hline Tannin $(\mathrm{mg} / 100 \mathrm{~g})$ & $67.07 \pm 3.77(\mathrm{a})$ & $32.1 \pm 3.65(\mathrm{~b})$ & $58.68 \pm 3.49(\mathrm{c})$ \\
Phytate $(\mathrm{mg} / 100 \mathrm{~g})$ & $78.11 \pm 1.86(\mathrm{a})$ & $66.91 \pm 1.09(\mathrm{~b})$ & $72.04 \pm 1.92(\mathrm{c})$ \\
Oxalate $(\mathrm{mg} / 100 \mathrm{~g})$ & $187 \pm 6.25(\mathrm{a})$ & $102 \pm 2.52(\mathrm{~b})$ & $58.33 \pm 2.08(\mathrm{c})$ \\
\hline
\end{tabular}

*Means having the same letter within rows are not significantly different at $\mathrm{p}<0.05$. Data were mean of three determinations $(\mathrm{n}=3)$.

Tannin: Results showed that tannin of the Boloso raw decreased significantly when processed boiled, fried and fermented. Boloso raw had the highest tannin (67.07 \pm 3.77 $\mathrm{mg} / 100 \mathrm{~g}$ ) while Boloso Fried has the lowest tannin content $(32.1 \pm 3.65 \mathrm{mg} / 100 \mathrm{~g})$.

Phytate: Boloso raw had the highest phytate $(78.11 \pm 1.86)$ and Boloso fermented had the lowest phytate
$(30.83 \pm 2.93)$. The phytate content of the Boloso raw significantly decreased upon boiling, frying and fermentation process.

Oxalate: Boloso row $(187 \pm 6.25 \mathrm{mg} / 100 \mathrm{~g})$ had the highest Oxalate content which significantly decreased when processed into fried, fermented and boiled (Table 2). Boiling reduced $69 \%$ of the oxalate found in the raw Boloso.

\subsection{Macro Nutrients}

Table 3. Mean macro nutrients present in raw and processed Boloso.

\begin{tabular}{lllll}
\hline components & P & Na & K & ca \\
\hline Boloso raw & $60.63 \pm 8.99(\mathrm{a})$ & $37.61 \pm 2.02(\mathrm{a})$ & $710.87 \pm 10.17(\mathrm{a})$ \\
Boloso fried & $67.39 \pm 15.57(\mathrm{~b})$ & $51.63 \pm 1.52(\mathrm{~b})$ & $301.96 \pm 53.19(\mathrm{~b})$ & $186.74 \pm 1.6(\mathrm{a})$ \\
Boloso boiled & $63.88 \pm 2.39(\mathrm{c})$ & $61.72 \pm 1.9(\mathrm{c})$ & $420.59 \pm 16.61(\mathrm{c})$ \\
Boloso fermented & $75.35 \pm 4.65(\mathrm{~d})$ & $67.54 \pm 0.24(\mathrm{~d})$ & $637.36 \pm 37.58(\mathrm{~d})$ & $184.81 \pm 3.62(\mathrm{~b})$ \\
\hline
\end{tabular}

*Means having the same letter within columns are not significantly different at $\mathrm{p}<0.05$.

Data were mean of three determinations $(n=3)$.

The presence of four macro minerals was investigated in the processed and unprocessed tubers shown in table 3 . Potassium was the most abundant macro mineral $(710 \mathrm{mg} / 100 \mathrm{~g})$ in the unprocessed tubers. Processing significantly reduced its content. 
The effect of processing on calcium showed significant increase upon fermentation and decrease on frying process. However, boiling did not significantly reduce the calcium content. When compared with Boloso raw, processing resulted in significant increase phosphorous and sodium content.

\subsection{Micro Nutrient}

Table 4. Mean micro nutrients present in raw and processed Boloso.

\begin{tabular}{llll}
\hline components & Cu & Zn & Fe \\
\hline Boloso raw & $0.76 \pm 0.02(\mathrm{a})$ & $14.27 \pm 0.93(\mathrm{a})$ & $10.57 \pm 0.74(\mathrm{a})$ \\
Boloso fried & $0.87 \pm 0.06(\mathrm{~b})$ & $13.69 \pm 0.5(\mathrm{a})$ & $5.95 \pm 0.48(\mathrm{~b})$ \\
Boloso boiled & $0.59 \pm 0.05(\mathrm{c})$ & $11.0 .6 \pm 0.15(\mathrm{~b})$ & $4.27 \pm 0.28(\mathrm{c})$ \\
Boloso fermented & $0.75 \pm 0.06(\mathrm{a})$ & $11.69 \pm 0.55(\mathrm{~b})$ & $4.21 \pm 2.74(\mathrm{c})$ \\
\hline
\end{tabular}

*Means having the same letter within columns are not significantly different at $\mathrm{p}<0.05$. Data were mean of three determinations $(\mathrm{n}=3$ ).

Table 4 briefs the micro nutrient content of Boloso raw, Boloso fried, Boloso boiled and Boloso fermented. Copper content of Boloso raw increased significantly when it is processed into fried while decreased significantly into boiled but the decrease in fermented form is not significant. Bolos raw has the highest zinc content $(14.27 \mathrm{mg} / 100 \mathrm{~g})$ and this zinc content decreased significantly upon boiling and fermentation process even though frying process decrease the content of zinc which is not significant. There was a noticeable decrease in iron content of Boloso raw when made into fermented, fried and boiled.

\section{Discussion}

\subsection{Proximate Composition of Taro}

\section{Moisture}

The moisture content of Boloso taro obtained from fresh taro corms was in the range of moisture content reported by FAO and research done on three local cultivar grown in Taiwan [15], [16]. The decrement in moisture content of Boloso Fried reduced significantly due to the application of higher temperature used in frying process caused loss of water through evaporation process [17]. While fermentation process increased the moisture significantly because it is soaked in water for $72 \mathrm{hrs}$ and absorbed more water due to the soft and porous structure of the endosperm.

Crude ash

Ash content of the Boloso raw taro obtained were 3.92 which was higher than $0.6-1.3 \%$ [18] and it was in the range of (3.54-7.78\%) reported by different authors [19], [20]. The observed difference in the ash contents may be attributed to climatic factor, the soil type, varietal and cultivar difference. From the high ash contents of the Boloso taro samples it could be inferred that there would be appreciable quantity of minerals in taro. Significant reduction of ash content of fried Boloso is related to exposure to high temperature that resulted in loss of minerals with volatile compounds and change in chemical nature [21], [22]. On the other hand significant reduction of ash content of Boloso boiled was due to leaching out of minerals from the corm [23], [24].

Crude Fiber

The crude fiber content of the fresh Boloso taro obtained from this study was higher than result obtained from five cultivars grown in Cameroon and Chad [20] but fall in between (5.02-9.01) values reported from nutritive contents done on taro grown in America Samoa [25]. Frying and boiling significantly reduced the fiber content owing to increase temperature resulted in cleavage of O-glycosidic bonds within and between glycosidic linkages in the dietary fiber polysaccharides [22], [26], [27]. The enzymatic degradation of the crude fiber by enzymes excreted by microorganisms involved in fermentation process resulted in bioconversion so that significant reduction in fiber content [28], [29].

Crude protein

Protein content of the Boloso raw taro fall within the range of $(5-7.2 \%)$ [30], but it was higher than the values obtained from research carried on six cultivars selected from Cameroon and Chad [15], [20]. Fermentation, boiling and frying processes significantly decreased crude protein content. Boiling and frying processes denatures protein structure as a result of high temperature. Boiling leached out soluble amino acids and resulted in decrease in crude protein content [23], [26], [27].

Fat

Crude fat content of Boloso raw cultivar used in this study was higher than the range reported by FAO, 1999 but fall in the range reported by different studies [20], [25]. Generally the fat content of Boloso raw decreased significantly when boiled and fermented. Boiling causes melting of the fat and it induces polymerization, decomposition and oxidation which can easily leached out caused loss in fat content [22], [31]. However, fried Boloso fat content was very high because it was cooked by vegetable oil.

\subsection{Anti-nutrient Content of Taro}

\section{Phytate}

Phytate acid binds to essential minerals, thus rendering them unavailable for intestinal uptake and unable to participate in essential metabolic process in the body. It affects protein structure that decreases enzymatic activity, solubility and proteolytic digestibility [32], [33]. Phytate concentration investigated in the Boloso raw taro in this study is $78.11 \mathrm{mg} / 100 \mathrm{~g}$ and it was below the values reported by FAO, 1990 and similar studies done on raw taro cultivars [16], [27], [34], [35]. It is in agreement with the values 
reported by Alcantra et al. on two varieties grown in Philippine [8]. The reduction in phytate content during boiling only takes place either by discarding the boiling water or enzymatic phytate hydrolysis due to the action of intrinsic plant phytase during early part of the cooking phase. The decrease in phytate content during boiling or frying may be partly due to the formation of insoluble complexes between phytate and other components of such phytateprotein or phytate-protein-mineral. Moreover, Phytate may be soluble under very high temperature like during boiling $\left(100^{\circ} \mathrm{C}\right)$ and baking $\left(190^{\circ} \mathrm{C}\right)$ as evident by the significant reduction of phytate content in frying and boiling [36].

On the other hand fermentation was effective processing method in reducing phytate when compared with boiling and frying [37], [38]. The reduction may be attributed to the activity of the endogenous phytase enzyme from the raw ingredient and inherent microorganisms which are capable of hydrolyzing the phytic acid in the fermented food preparations intoinositol and orthophosphate [39], [40].

\section{Tannin}

Tannin is water soluble compound having high molecular weight and largely influences the nutritive values. It has special properties such as ability to precipitate alkaloids, gelatins and proteins. Food rich in tannin are considered to be low nutritional value because they precipitate proteins, inhibits digestive enzymes and reabsorption. It affects utilization of vitamins and minerals from meals [41].

In this study the amount the amount of tannin from Boloso Raw was $67.07 \mathrm{mg} / 100 \mathrm{~g}$ which is higher than similar studies done on raw taro [8], [42], [43]. From the result obtained in this study boiling, frying and fermentation resulted in significant decrease in tannin and highest decrease observed in frying process. This result agrees with the findings of researches done on effects of processing on anti-nutritional factors on taro cultivars [44], [45]. The observed decrease in tannin content due to boiling may be leach out the hydrolysable tannin in boiling water. Reduction of tannin brought by the fermentation is due to the action of enzymes excreted by the micro organism which involve in the fermentation process [8], [34], [42].

\section{Oxalate}

Most cultivars of taro contain oxalic acid mainly in the form of "raphides" that is bundles of needle-shaped crystals of calcium oxalate embedded in the tissue. Oxalates are major anti-nutritional factors present in taro FAO, 1999 [15]. The presence of oxalate gives them acrid taste or cause irritation when eaten. Oxalate can have a harmful effect by reducing calcium absorption and aiding the formation of kidney stone [46]. Calcium oxalate content in giant taro corm depends on the cultivars, fertilizers and environmental condition, especially during drought [18]. Since the allowable calcium oxalate content in food is only $71 \mathrm{mg} / 100$ $\mathrm{g}$, therefore taro corms require proper processing method to reduce the calcium oxalate content to a safe level [47].

The level of oxalate obtained for the Boloso raw samples in this study were smaller than the values obtained by different authors [16], [25], [34], [35], [48]. But the values are similar with studies done on the effect of cooking on the concentration of oxalate in taro varieties grown in Cambodia, New Zealand and Philippines [8], [49], [50]. This value is higher than studies done on drying phenomenon on antinutritional factors [51] and effect of processing methods on oxalate content on taro cultivars grown in South Africa [43]. Boiling treatments were found to be effective reducing the oxalate content of tuber under investigation. The highest loss of oxalate occurred when boiling the Boloso raw. Boiling causes considerable cell rupture and facilitate the leakage of soluble oxalate into cooking water and all observed the same trend [16], [49], [53], [54], [55], [56].Fermentation decreased the oxalate concentration significantly. Oke and Bolarinwa [57] reported that the $65 \%$ reduction of oxalates of taro was observed in 48 hours of fermentation and similar studies showed a decrease in oxalate content in fermentation process [28], [42]. Treatment process done prior to frying like washing, peeling, dicing as well as soaking could reduce the oxalate concentration. It was also found out that soaking reduce the concentration of oxalate by $23.5 \%$ and cooking by $56.7 \%$ [16]. When the samples were fried, there was a significant decrease in oxalate content.

\subsection{Macro Nutrients}

The presence of four macro minerals was investigated in the processed and unprocessed tubers. Potassium was the most abundant macro mineral $(710 \mathrm{mg} / 100 \mathrm{~g})$ in the unprocessed tubers. Calcium was the second most common mineral $(186 \mathrm{mg} / 100 \mathrm{~g})$, third most mineral was phosphorous $(60 \mathrm{mg} / 100 \mathrm{~g})$ and appreciable amount of sodium $(37 \mathrm{mg} / 100 \mathrm{~g})$ was also noted.

The mean content of phosphorus, sodium, potassium and calcium of the investigated Boloso raw taro was higher than those similar studies done on raw taro [34], [35], [58]. However, it is consistent with research report by FAO, 2003 and studies done on different taro cultivars [19], [59], [60], [61], [62]. In general, processing led to significant increase in phosphorus and this was also supported by the findings of Abera et al. [34] where the Phosphorus composition of taro raised significantly after boiling and fermentation. Mean concentration Sodium was also increased significantly upon processing. This finding is supported by Abera et al. [34] where boiling increased sodium whereas fermentation decreased its concentration in contrary to current report of the investigation. Frying process increased the content of both sodium and potassium.

Processed samples of Boloso tuber showed significant reduction in potassium content than raw taro. This was also supported by the findings of Akpan and Umoh where the mineral composition of $\mathrm{X}$. sagittifolium corms dropped significantly after cooking [45]. The slight decrease in calcium contents in boiling process were due to water absorption and leaching during boiling. Significant reduction of calcium and potassium content during frying as a result of destruction, chemical changes like oxidation and may be calcium and potassium partly loss as volatile compounds contributing to the reduction [24], [23]. Fermentation process 
significantly increases the calcium content and it significantly decreased in potassium content of fermented taro is due leaching process.

\subsection{Micronutrients}

With regard to micronutrients, zinc has the most abundant with $14.27 \mathrm{mg} / 100 \mathrm{~g}$ as a mean value for the unprocessed Boloso. The result obtained from this study on micronutrients is higher than reported by different research findings on the effect of processing on micronutrients [8], [19], [58], [63], however; the result was in accordance with the study done on taro cultivars grown in Ethiopia [34], [35].

The reduction in mineral contents of micronutrients during Frying process the taro were due to higher temperature $\left(190^{\circ} \mathrm{C}\right)$ which causes mineral degradation as a result of destruction or chemical changes like oxidation. Moreover, as heating continued, some of the mineral elements such as zinc, iron and copper may be partly loss as volatile compounds contributing to the reduction in the mineral content [23], [24]. Fermented sample of Boloso taro tuber was lower in iron and zinc, while the copper content was not affected by fermentation, than in the raw samples. This is may be due to leaching of the mineral compounds into water in the process of fermentation for 72 hours. Boiling process reduced the iron content it may be due to leaching of the mineral compounds into the boiling water but this process increased the copper content [22].

\section{Conclusion}

Boloso species was analyzed and found to be a good source of carbohydrate, rich in both macro and micro nutrients such as potassium, calcium, phosphorous, zinc and iron. Most plant foods also consist of anti-nutrients that appear to function generally in defense against herbivores and pathogens. Anti-nutrients are potentially harmful for humans. They prevent digestion and absorption of vitamins, minerals and other nutrients and resulting in chronic deficits. Boloso raw contains some anti-nutritional factors such as high oxalates, phytates and tannins which can limit the utilization of taro nutrients for human consumption and animal feed.Traditional processing of Boloso taro significantly reduced all the anti-nutrients that were analyzed in this study.

\section{References}

[1] Food and Agriculture Organization of the United Nations.(1997). Agriculture food and Nutrition for Africa: are source book for teachers of agriculture. Rome: FAO Information Division. [online].Available from: http://www.cyberlipid.org/index.htm

[2] Umeta M, West CE, Fufa H. (2005). Content of zinc, iron, calcium and their absorption inhibitors in foods commonly consumed in Ethiopia. J Food Comp Anal. 18:803-17.

[3] Ejoh, S.I., V.A. Obatolu, O.T. Olanipekun and E.O. Farinde.
(2013). Extending the use of an underutilised tuber I: Physicochemical and pasting properties of cocoyam (Xanthosoma sagittifolium) flour and its suitability for making biscuits. Afr. J. Food Sci. 7: 264-273.

[4] Lebot, V. (2009). Tropical root and tuber crops: Cassava, sweet potato, yams and aroids. Wallingford: CABI International (Chapter 22).

[5] Lebot, V., Quero-García, J. and Ivancic, A. (2006b). Comparative performance of local and introduced cultivars of taro (Colocasia esculenta (L.) Schott) in Vanuatu. ISTRC Symposium, CTCRI, Trivandrum, India.

[6] John J, Cho Roy A, Yamakawa R and J Hollyer. (2007). Hawaiian Kalo Past and future, Corporative Extension service, college of Tropical Agriculture and Human Nutrition, University of Hawaii at Manoa:8p.

[7] Arinathan V, Mohan VR, Maruthupandian A. (2009). Nutritional and antinutritional attributes of some underutilized tubers. Trop.Subtrop. Agroeco. 10: 273 - 278.

[8] Richelle M Alcantara, Wilma A Hurtada and ErlindaDizon.(2013). The Nutritional Value and Phytochemical Components of Taro [Colocasia esculenta (L.) Schott] Powder and its Selected Processed Foods. J Nutr Food Sci. 3(3):207.

[9] Bassir, O. (1969). Toxic substances in Nigerian foods. West African Journal of Biochemistry and Applied Chemistry. 13: 3-6.

[10] Liebman M. (2002). The truth about oxalate: answers to frequently asked questions. The Vulvar Pain News letter, no.22 [online].Available from: <http//_www. vulvar pain foundation.org/vpf news letteLhtm>.

[11] Steiner T., Mosenthin R., Zimmerman B., Greiner R. And Roth S. (2007). Distribution of Phytase activity, total phosphorus and phytate phosphorus in legume seeds, cereals and Cereal by-products as influenced by harvest year and cultivar. Animal Feed Science and Technology.133: 320-334.

[12] Natural Resource Institute, (NRI), (1987).Root crops, second edition.

[13] AOAC Official Methods of Analysis (1984), $16^{\text {th }}$ Edition, vol. 18. Association of Official Analytical Chemists, Arlington, VA., p 24-31.

[14] AOAC (1990) Official methods of analysis, 15th ed., vol. 25. Association of Official Analytical Chemists, Arlington, VA., 47-53.

[15] FAO, (1999).Taro cultivation in Asia and the Pacific, Food and Agriculture Organization of the United Nations, (FAO), Rome, Italy.

[16] Huang Chien-Chun Woan-Ching Chen, Ciun-C.R. Wang,(2007).Comparisons of Taiwan paddy and uplandcultivated taro (Colocasia esculenta L.)cultivars for nutritive values. Food Chemistry. 102:250-256.

[17] Tekle A. (2009). The Effect of Blend Proportion and Baking Condition on the Quality of Cookie Made from Taro and Wheat Flour Blend. Master's Thesis. Addis Ababa University, Ethiopia.

[18] Bradbury, J. H. and Holloway, W. D. (1988). Chemistry of Tropical Root Crops: Significance for Nutrition and Agriculture in the Pacific. Canberra: Australian Centre for International Agricultural Research. 
[19] Njoku P.C. and C.C. Ohia, (2007). Spectrophotometric Estimation Studies of Mineral Nutrient in Three Cocoyam Cultivars. Pakistan Journal of Nutrition. 6: 616-619.

[20] Mbofung, C.M.F., Aboubakar, Y.N. Njintang, A.Abdou Bouba and F.Balaam.(2006). Physicochemical and Functional Properties of Taro (Colocasia esculenta L. Schott) Flour. Journal of Food Technology. 4(2): 132-142.

[21] Lewu MN, Adebola PO, Afolayan AJ. (2010). Effect of cooking on the mineral contents and anti-nutritional factors in seven accessions of Colocasia esculenta (L.) Schott growing in South Africa. Journal of Food Composition and Analysis. 23: 389-393.

[22] Lola A (2009). The effect of boiling on the nutrients and antinutrients in two non conventional vegetables. Pak J Nutr. 8: 1430-1433.

[23] Olajide R, Akinsoyinu AO, Babayemi OJ, Omojola AB, Abu AO. (2011). Effect of Processing on Energy Values, Nutrient and Anti-nutrient Components of Wild Cocoyam [Colocasia esculenta (L.) Schott] Corm. Pak J Nutr. 10: 29-34.

[24] Jacobs MB. (1972). The Chemistry and Technology of Food and Food Products. ( $\left.2^{\text {nd }} \mathrm{ed}\right)$. Interscience Publishers, Inc, New York, USA.

[25] Nip W, Muchille J, Cai T and JH Moy. (1989).Nutritive and Non-nutritive Constituents in Taro (Colocasia esculenta (L.) Scott) from American Samoa. Journal of Haw. Pac. Agri. 2: 1-5.

[26] Agoreyo BO, Akpiroroh O, Orukpe OA, Osaweren OR, Owabor CN. (2011). The Effects of Various Drying Methods on the Nutritional Composition of Musa paradisiaca, Dioscorea rotundata and Colocasia esculenta. Asian Journal of Biochemistry. 6: 458-464.

[27] FAO, (1990).Roots, tubers, plantain and bananas in human, Nutrition.Food and Agriculture Organization of the United Nations, (FAO), Rome Italy.

[28] Igbabul B.D, Amove J. and Twadue I. (2014). Effect of fermentation on the proximate composition, anti-nutritional factors and functional properties of cocoyam (Colocasia esculenta) flour. African Journal of Food Science and Technology. 5(3): 67-74.

[29] Abang, F.B and Shittu, H. A. (2015). Effect of Fermentation on the Chemical Composition of Peeled Taro Cocoyam Meal (Colocasia Esculenta Var Esculenta). IOSR-JAVS. 8(3): 31-33.

[30] Treche, Serge (1996). Tropical Root and Tuber Crops as Human Staple Food. Latin American Congress of Tropical Roots. October 7-10.

[31] Fennema O. (1976). Principles of Food Science. Marcel Dekker, Inc., New York.

[32] Greiner R, Konietzny U, and Jany KD. (2006). Phytate - an undesirable constituent of plant based foods? Journal für Ernährungsmedizin. 8 (3): 18-28.

[33] John Shi, Konesh Arunasalam David Yeung, Yukio Kakuda and Gauri Mittal. (2004).Phytate from edible beans: chemistry, processing and health benefits. Food, Agriculture \& Environment. 2 (1): 49-58.

[34] Tilahun Abera Teka, Shimelis Admassu Emire, Gulelat Desse Haki, Tilahun Bekele Gezmu. (2013). Effect of processing on physicochemical composition and anti-nutritional factors of cassava (manihot esculenta crantz) grown in Ethiopia. International Journal of Science Innovations and Discoveries. 3(2): 212-222.

[35] Esayas Ayele, Kelbessa Urga and Bhagwan Singh Chandravanshi. (2015). Effect of Cooking Temperature on Mineral Content and Anti-nutritional Factors of Yam and Taro Grown in Southern Ethiopia. Int. J. Food Eng.

[36] Adane T, Shimelis A, Negussie R, Tilahun B, GD Haki. (2013). Effect of processing method on the proximate composition, mineral content and antinutritional factors of taro (Colocasia esculenta, 1.) grown in Ethiopia. African journal of Food, Agriculuture, Nutrition and Development. 13(2):7383-7398.

[37] Vijayakumari, K., Siddhuraju, P., \& Janardhanan, K. (1997). Effect of domestic processing on the levels of certain antinutrients in Prosopischilensis (Molina) Stunz. Seeds. Food Chemistry. 59(3): 367-371.

[38] Saikia, P., Sarkar, C. R., \& Borua, I. (1999). Chemical composition, anti-nutritional factors and effect of cooking on nutritional quality of rice bean [Virgna umbellate (Thunb; Ohwi and Ohashi)]. Food Chemsitry. 67: 347-352.

[39] Reddy NR, Pierson MD. (1994). Reduction in antinutritional and toxic components in plant foods by fermentation. Food Res. Int. 27: $281-290$.

[40] Sandberg AS, Andlid T. (2002). Phytogenic and microbial phytases in human nutrition. Int. J. Food Sci. Technol. 37:823833.

[41] Tinko N and K Uyano. (2001). Spectrophotometric determination of the tannin contents of various Turkish black tea, beer and wine samples. International Journal of Food Sciences and Nutrition. 52: 289-294.

[42] Abang, F.B and Shittu, H. A. (2015). Effect of Fermentation on the Chemical Composition of Peeled Taro Cocoyam Meal (Colocasia Esculenta Var Esculenta). IOSR-JAVS. 8(3): 31-33.

[43] R. Mc Ewan, F.N. Shangase, T.Djarova and A.R. Opoku. (2014). Effect of three processing methods on some nutrient and anti nutritional factor constituents of Colocassia Esculenta (Amadumbe).AJFS. 8(5):286-291.

[44] Onu, P. N., \& Madubuike, F. N. (2006). Effect of raw and cooked wild cocoyam (Caladium bicolor) on the performance of broiler chicks. Agricultura Tropica et Subtropica. 39(4):273-278.

[45] Akpan, E. J., \& Umoh, I. B. (2004). Effect of Heat and Tetracycline Treatments on the Food Quality and Acridity Factors in Cocoyam [Xanthosoma sagittifolium (L.) Schott].Pakistan Journal of Nutrition.3(4): 240-243.

[46] Noonan S., \& Savage, G. P. (1999). Oxalate content of food and its effect on humans. Asia Pacific Journal of Clinical Nutrition. 8(1): 64-74.

[47] Sefa-Dedeh, S. and Agyir-Sackey, E. K. (2004). Chemical composition and the effect of processing on oxalate content of cocoyam Xanthosoma sagittifolium and Colocasia esculenta cormels. Food Chemistry. 85:479-487.

[48] Catherwood, D. J., Savage, G. P., Mason, S. M., Scheffer, J. J. C., \& Douglas, J. A. (2007). Oxalate content of cormels of Japanese (Colocasia esculenta(L.) Schott) and the effect of cooking. Journal of Food Composition and Analysis. 20: 147-151. 
[49] Albihn PB and GP Savage. (2001). The effect of cooking on the location and concentration of oxalate in three cultivars of New Zealand-grown oca (Oxalis tuberose Mol). Journal of the Science of Food and Agriculture. 81:1027-1033.

[50] Buntha P, Borin K, Preston T, Ogle B. (2008). Survey of taro varieties and their use in selected areas of Cambodia. Livestock Research for Rural Development 20.

[51] J. A. V. Famurewa,, J. B. Olatujoye, and A. Ajibode. (2014). Drying Phenomenon and Influence on the Anti Nutritional and Pasting Properties of Cocoayam (Taro). Journal of Scientific Research \& Reports. 3(2): 275-283.

[52] Iwuoha I and A Kalu. (1994). Calcium oxalate and physicochemical properties of cocoyam (Colocasia esculenta and Xanthosoma sagittfolium) tuber flours as affected by processing. Food Chem. 54: 61-66.

[53] Sang ketkit C., Savage G.P., Martin R.J.andMason SM. (2001). Oxalate content of raw and cooked oca (Oxalis tuberosa). Journal of Food Composition and Analysis. 14:389397.

[54] Savage G.P. (2002). Oxalates in human foods.Proceedings in the Nutrition Society of New Zealand. 27:4-24.

[55] Quinteros A, Farre R and Lagarda MJ. (2003). Effect of cooking on oxalate content of pulses using an enzymatic procedure. International Journal of Food Sciences and Nutrition.54:373-377.

[56] Catherwood, D. J., Savage, G. P., Mason, S. M., Scheffer, J. J. C., \& Douglas, J. A. (2007). Oxalate content of cormels of Japanese (Colocasia esculenta(L.) Schott) and the effect of cooking. Journal of Food Composition and Analysis. 20: 147151.
[57] M. O. Oke and I. F. Bolarinwa. (2012). Effect of Fermentation on Physicochemical Properties and Oxalate Content of Cocoyam (Colocasia esculenta) Flour. ISRN Agronomy. 2012:1-4.

[58] Andrej Mergedus, JanjaKristl,Anton Ivancic, Andreja Sober,VilmaSustar, TomazKrizan, Vincent Lebot. (2015). Variation of mineral composition in different parts of taro (Colocasia esculenta) corms. Food Chemistry.170:37-46.

[59] FAO (2003) EDIBLE AROIDS: Post-Harvest Operation. Massey University, Private Bag 11-222, Palmerston North, New Zealand.

[60] HuangA. S.,C. A. Titchenal and B. A. Meilleu. (2000). Nutrient Composition of Taro Corms and Breadfruit. Journal of Food Composition and Analysis.13:859-864.

[61] Adeyeye EI, Arogundade LA, Akintayo ET, Aisida OA, Alao PA. (2000). Calcium, zinc and phytate interrelationships in some foods of major consumption in Nigeria. Food Chem $71: 435-41$.

[62] Kumoro A. C., Budiyati C. S. and Retnowati D. S. (2014). Calcium oxalate reduction during soaking of giant taro (Alocasia macrorrhiza (L.) Schott) corm chips in sodium bicarbonate solution. International Food Research Journal. 21(4): 1583-1588.

[63] Anon Simplice Amon, René Yadé Soro, Emma Fernande Assem and, Edmond Ahipo Dué, Lucien Patrice Kouamé. (2014). Effect of boiling time on chemical composition and physico-functional properties of flours from taro (Colocasia esculenta cv fouê) corm grown in Côte d'Ivoire. J Food Sci Technol. 51(5):855-864. 